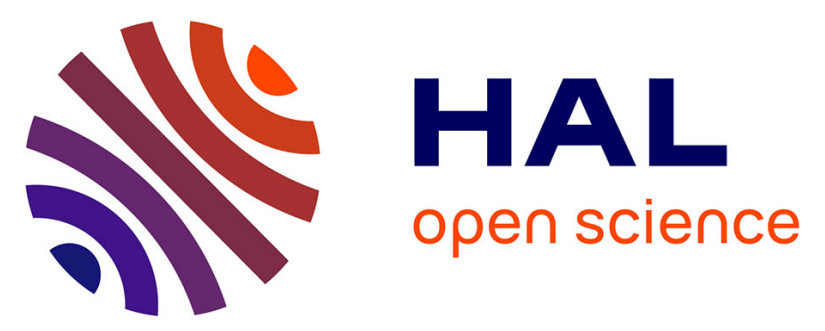

\title{
Microbiota abnormalities in autism spectrum disorders: a pilot comparison in a cohort of adult patients and healthy controls
}

A. Gaman, G. Iamandi, S. Le Fresne, J. Dubreucq, A. Teruel Martinez, D. Monnet, N. Simohammed, E. Murzi, J. Houenou, M. Cazaubiel, et al.

\section{To cite this version:}

A. Gaman, G. Iamandi, S. Le Fresne, J. Dubreucq, A. Teruel Martinez, et al.. Microbiota abnormalities in autism spectrum disorders: a pilot comparison in a cohort of adult patients and healthy controls. 30th Congress of the European-College-of-Neuropsychopharmacology (ECNP), Sep 2017, Paris, France. pp.1. hal-02734727

\section{HAL Id: hal-02734727 \\ https://hal.inrae.fr/hal-02734727}

Submitted on 2 Jun 2020

HAL is a multi-disciplinary open access archive for the deposit and dissemination of scientific research documents, whether they are published or not. The documents may come from teaching and research institutions in France or abroad, or from public or private research centers.
L'archive ouverte pluridisciplinaire HAL, est destinée au dépôt et à la diffusion de documents scientifiques de niveau recherche, publiés ou non, émanant des établissements d'enseignement et de recherche français ou étrangers, des laboratoires publics ou privés.

\section{다(1)(2)}

Distributed under a Creative Commons Attribution - ShareAlikel 4.0 International 


\section{References}

[1] McGorry, P., Keshavan, M., Goldstone, S., Amminger, P., Allott, K., Berk, M., Hickie, I., 2014. Biomarkers and clinical staging in psychiatry. World Psychiatry 13 (3), 211-223. doi: 10.1002/wps. 20144

[2] Bortolato, B., Miskowiak, K.W., Köhler, C.A., Vieta, E., Carvalho, A F., 2015. Cognitive dysfunction in bipolar disorder and schizophrenia: A systematic review of meta-analyses. Neuropsychiatric Disease and Treatment 11, 3111-3125. doi: 10.2147/NDT.S76700

[3] Li, L., Dong, M., Wang, X.G., 2016. The implication and significance of beta 2 microglobulin: A conservative multifunctional regulator Chinese Medical Journal 129 (4), 448-455. doi: 10.4103/0366-6999. 176084

[4] Smith, L.K., He, Y., Park, J.-S., Bieri, G., Snethlage, C.E., Lin, K Villeda, S.A., 2015. B2-microglobulin is a systemic pro-aging factor that impairs cognitive function and neurogenesis. Nature medicine 21 (8), 932-937. doi: 10.1038/nm.3898

[5] Chittiprol, S., Venkatasubramanian, G., Neelakantachar, N., Allha, N., Shetty, K.T., Gangadhar, B.N., 2009. B2-Microglobulin abnormalities in antipsychotic-naïve schizophrenia: Evidence for immune pathogenesis. Brain, Behavior, and Immunity 23 (2), 189-192. doi: 10 . 1016/j.bbi.2008.08.007

\section{P.1.f.024 Microbiota abnormalities in autism spectrum disorders: a pilot comparison in a cohort of adult patients and healthy controls}

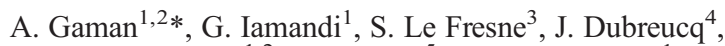
A. Teruel Martinez ${ }^{1,2}$, D. Monnet ${ }^{5}$, N. Simohammed ${ }^{1}$, E. Murzi ${ }^{1}$, J. Houenou ${ }^{1,6}$, M. Cazaubiel $^{3}$, J. Dore ${ }^{7}$, M. Leboyer ${ }^{1,2}{ }^{1}{ }^{1}$ Expert Center "Asperger", "Henri Mondor" Hospitals-Créteil- Ile-deFrance, Psychiatry, Créteil, France; ${ }^{2}$ INSERM U955

Translational Psychiatry, Psychiatry, Créteil, France; ${ }^{3}$ Biofortis Mérieux NutriScience, Nutrition, Saint-Herblain, France; ${ }^{4}$ Centre Expert « Asperger 》 Grénoble-, Hospital Center Alpes-IsèreGrénoble, Psychiatry, Grenoble, France; ${ }^{5}$ Expert Center

"Asperger", "Henri Mondor" Hospitals-Créteil-Ile-de-France, Psy, Créteil, France; ${ }^{6}$ Biomedical Imaging Institute- UNIACT, Neurospin, Neuroimaging, Saclay, France; ${ }^{7}$ French National Research Institute of Agronomy INRA, Microbiology, Jouy-enJosas, France

Background and rationale: Autism Spectrum Disorders is a group of psychiatric conditions with an increasing prevalence in the general population (1 in 68, Center for Disease Control and Prevention, 2010) and presenting with debilitating symptoms in area of social communication, empathy and repetitive behaviours. Recent animal studies unveiled the link between intestinal microbiota abnormalities, intestinal hyper-permeability changes and cerebral modifications that seemed to be associated with ASD symptoms (1). Similar microbiota changes have also been observed in ASD patients where increased proportions of Firmicutes (2) and Bacteoidetes (3) phyla have been observed. With a small number of studies available looking to the structure of microbiota in ASD patients, this domain is still evolving and further clarification is sought by the psychiatric world. A previous systematic review (4) reports a positive signal and calls for further data collection.

Our pilot study proposes to leverage the understanding of the microbiota roles in ASD. Our working hypothesis is that ASD patients present abnormalities in diversity and richness that lead to metabolomic abnormalities, eventually impacting the cerebral activity.
Material and methods: 15 ASD subjects without intellectual deficit diagnosed by a group of experts in the field of autism ("Asperger" Expert Centers Créteil and Grenoble) and 12 adult healthy controls were included for the microbiota analysis. The faecal samples were collected using an auto-collection kit (microbiome-standards.com SOP05) and the microbiota analysed using PCR amplified bacterial 16S ribosomal DNA (V3-V4 region Miseq, Illumina). Mean values of richness (Chao index) and diversity (Shannon index) at genus, phylum and family level were determined to describe the bacterial population.

Results: Trends of difference were observed at phylum level: Bacteroidetes and Firmicutes were slightly more abundant in ASD subjects while Actinobacteria and Proteobacteria were more abundant in controls. At family level Prevotellaceae is trending more abundant in controls while Bacteroidaceae more in ASD subjects. The index of richness (Chao) was similar for ASD and for controls, set at around 6500 operational taxonomic units (OTU). The diversity index tended to be lower in ASD patients (mean $4.75, \mathrm{CI}=(4.39-5.24))$ versus controls (mean 4.90, $\mathrm{CI}=$ $(4.35-5.65))$.

Discussion: the results obtained showed that the bacterial population in ASD subjects tends to present a different, abnormal structure when compared to healthy controls: less diverse and with certain strains more abundant. Differences in composition could be associated with different bacterial metabolic products such as short chain fatty acids but also alterations of the intestinal wall permeability (hyper-permeability) and overall inflammatory tone. The fermentation products can pass in increased amounts in the blood and brain, inducing an abnormal cerebral activity, that could contribute to ASD symptoms. As future direction, the findings in this study will be further extended by enlarging significantly the cohort but also correlated with other biomarkers such as metabolomic profiles, inflammation signaling molecules, and cerebral activity.

\section{References}

[1] Hsiao, E.Y., McBride, S.W., Hsien, S., Sharon, G., Hyde, E.R. McCue, T., et al., 2013. Microbiota modulate behavioral and physiological abnormalities associated with neurodevelopmental disorders. Cell 155 (7), 1451-1463.

[2] Finegold, S.M., Molitoris, D., Song, Y., Liu, C., Vaisanen, M.L., Bolte, E., et al., 2002. Gastrointestinal microflora studies in late-onset autism. Clin Infect Dis Off Publ Infect Dis Soc Am 35 (Suppl 1), S6S16.

[3] Finegold, S.M., Dowd, S.E., Gontcharova, V., Liu, C., Henley, K.E., Wolcott, R.D., et al., 2010. Pyrosequencing study of fecal microflora of autistic and control children. Anaerobe 16 (4), 444-453.

[4] Cao, X., Lin, P., Jiang, P., Li, C., 2013. Characteristics of the gastrointestinal microbiome in children with autism spectrum disorder: a systematic review. Shanghai Arch Psychiatry 25 (6), 342-353.

\section{P.1.f.026 Prolyl endopeptidase is involved in the degradation of neural cell adhesion molecules}

K. Jaako ${ }^{1}$, A. Noortoots ${ }^{2}$, A. Aonurm-Helm ${ }^{2}$, A. Zharkovsky ${ }^{2}$

${ }^{I}$ University of Tartu, Institute of Biomedicine and Translational Medicine, Department of Pharmacology, Tartu, Estonia; ${ }^{2}$ Institute of Biomedicine and Translational Medicine, Department of Pharmacology, Tartu, Estonia

Neural cell adhesion molecule (NCAM) is membrane-associated protein required for the dynamic connection of neurons to each 